\title{
2013
}

Working Paper

(1)

INSTITUTO DE POLITICAS Y BIENES PÚBLICOS [DPP]

\section{CITIZENS' SUPPORT FOR GOVERNMENT SPENDING ON SCIENCE AND TECHNOLOGY.}

LUIS SANZ-MENÉNDEZ, GREGG VAN RYZIN

\&

Eloísa del Pino 


\section{INSTITUTO DE POLÍTICAS Y BIENES PÚBICOS - CSIC}

Copyright (C2013. Sanz-Menéndez, L., Van Ryzin,, G. \& del Pino, E. All rights reserved.

Instituto de Políticas y Bienes Públicos

Consejo Superior de Investigaciones Científicas

C/ Albasanz, 26-28

28037 Madrid (España)

Tel: +34916022300

Fax: +34 913045710

http://www.ipp.csic.es

How to quote or cite this document:

Sanz-Menéndez, L., Van Ryzin,, G. \& del Pino, E . (2013) Citizen's support for government spending on science and technology. Instituto de Políticas y Bienes Públicas (IPP) CSIC, Working Paper. 2013-01.

Available at: digital.csic.es 


\title{
Citizens' support for government spending on science and
}

\section{technology}

\author{
Luis Sanz-Menéndez*, Gregg G. Van Ryzin\$ and Eloisa del Pino* \\ * Institute of Public Goods and Policies (IPP), Consejo Superior de Investigaciones Científicas (CSIC), C/ Albasanz 26-28, \\ 28037 Madrid (Spain) \\ ${ }^{\$}$ School of Public Affairs and Administration (SPAA), Rutgers University-Newark, 111 Washington Street, Newark, NJ \\ 07102-1801 (United States)
}

PREPRINT. To be published in Science and Public Policy http://spp.oxfordjournals.org/

\begin{abstract}
This paper analyses public support for government spending on science and technology (S\&T) and its determinants. It constructs hypotheses based on previous findings from two streams of research: public preferences for government spending and public understanding of science. Using data from a large national survey in Spain, it develops multivariate models to test the relevance of various predictors of public support for government spending on S\&T. Findings identify several variables that are clear and consistent predictors of public support for government spending on science and technology: the respondent's educational level, interest and participation in science, knowledge of science, and positive values and views of science and technology. However, the effects of other variables also related with general attitudes toward science are less clearly associated with support for government spending on S\&T.
\end{abstract}

Key words: government spending, policy preferences, science and technology policy, interested and knowledgeable citizens, public understanding of science and technology, science and the public.

Corresponding author email: Luis.Sanz@csic.es 


\section{Introduction}

World expenditure on research and development (R\&D) in 2007 totaled more than 1.1 trillion US dollars (estimated in PPP), representing more than $2 \%$ of world annual GDP (NBS-NSF 2010). And over the last 15 years, global R\&D expenditure has doubled in real terms. Despite the fact that science and technology have become powerful sources of innovation and economic benefits for private actors, governments continue to finance almost half of global expenditure on R\&D. Additionally, there are more than 6 million researchers worldwide, and many more than half work either for governments or public higher education institutions (OECD 2011). While government funding of science and technology $(\mathrm{S} \& \mathrm{~T})$ is a relevant public policy issue, little is known about how much citizens support government spending on science and technology and what factors influence their support.

Understanding citizens' support for government spending on S\&T or attitudes towards fiscal prioritization of R\&D in public policy is an important topic for several reasons. First, government S\&T spending has become a salient and significant policy issue and, increasingly, it is linked to ambitious policy targets. Many countries have established political commitments to increase gross expenditure on R\&D (e.g. European Union Lisbon Objectives up to 3\% in 2010) and public funding of research (Sheehan \& Wyckoff 2003). Second, there is a tension between elites, experts and policy makers (Prpic 2011) who call for substantive increases in R\&D expenditures and the general public who often appear indifferent towards science and technology policy and government spending, despite the reported interest in scientific discoveries (by NSF or Eurobarometers). Thus, it may be that interest in science does not necessarily mean that people are willing to pay for it. Third, despite recognition of the correlations between investment in science and technology and growth rates (e.g. Nelson \& Romer 1996), governments facing fiscal consolidation have to make choices about where and how much to cut among many different programs and in some policy areas, in democratic societies, public opinion shapes the outcomes (Burstein, 2003) and often acts as a constraint for making policy choices, leading governments to align their decisions with the preferences and priorities of citizens as much a as

with the relevance of science to the society and economy (Anichini and de Cheveigné 2012). Last but not least, very little is know about the factors that explain public support for government 
spending on S\&T, compared with what is known about citizens' support for other areas of government spending.

Since the early eighties, US and European opinion surveys have asked periodically whether the "government is spending too little, too much or about the right amount for the conduct of scientific research" (Miller 2004): that is about government spending in S\&T. However, citizens' support for S\&T policies and spending is an issue that has mainly been analyzed indirectly, through the study of citizens' interest in science, scientific literacy, and other general attitudes towards science and technology; this last approach is generally known as public understanding of science.

To advance knowledge on this topic, the main objective of this paper is to examine various predictors of citizens' support for government S\&T spending. And in particular, we seek to establish the extent to which citizens' support for S\&T spending can be explained by the same determinants that account for more general attitudes toward science and technology. The focus of this paper, it should be noted up front, is on public support for S\&T government spending in Spain in the more stable period before the current economic crisis. Recent research has found changes in public attitudes toward science and S\&T policy in Spain as a result of economic crisis, with evidence suggesting that public support for S\&T may actually have increased in the post-crisis period (Sanz-Menéndez and Van Ryzin 2013). Of course, all research based on surveys and public opinion studies is context dependent, but still our data are unique in that they contain a rich set of variables that permit an empirical test of some standard explanations of citizen support for government spending in this important area, that is without doubt a relevant dimension of S\&T policy.

The paper is organized as follows: in section 2, we provide a background review of the problem and we present the analytical framework. Section 3 describes the data, measures and statistical methods. Section 4 presents the findings of our analysis. Finally, in Section 5 we discuss the results, policy implications and suggestions for future research.

\section{Background and analytical framework}

Studies of the public understanding of science have implicitly assumed that support for government S\&T spending correlates positively with more general attitudes towards science. However, there exists a vast and sophisticated literature on citizen attitudes toward government 
spending in general and in specific policy areas. In our paper, we draw on insights emerging from both of these areas of research to empirically account for support for government expenditure for S\&T.

The study of citizens' preferences toward public spending attracted attention in the 1960s and 1970s when government economic intervention began to be increasingly questioned. Early studies of attitudes toward government spending have found ambivalent attitudes (Free \& Cantril 1967; Sears \& Citrin 1985). On one hand, citizens seem to be wary of state intervention, taxes, and public spending in general. On the other, they appear more open and supportive of increased public spending in specific areas of policy or on particular public goods or programs. This ambivalence has led some politicians to favour cuts in public spending to defend their ideas in general terms, while those who support continuing government intervention frame their proposals in terms of specific policies and programs (Jacoby 2000).

Moreover, literature on citizen attitudes toward government spending informs us that patterns of citizens' preferences vary substantially depending on the sector of public policy and across countries (Soroka and Wlezien 2010). However, the main contribution of this literature is related to the determinants of attitudes towards public spending. Although a single structure of determinants of attitudes towards public spending cannot be identified across all policies and programs (Monroe 1979; Jacoby 1994; Carrillo and Tamayo 2011), this literature, especially regarding welfare policies, suggests that socio-demographic factors (as an expression of selfinterest) and ideological variables (such as redistributive principles) are the best predictors of attitudes towards public spending (Blekesaune and Quadagno 2005). The different contexts, the nature, features or outcomes of these policies are likely to condition citizens' attitudes toward public spending too (Svallfors 2003). In the case of S\&T policies, the vast public spending in science, exemplified by the Apollo space program in the US, prompted public debate. In response, the US National Science Foundation promoted the systematic analysis of public opinion regarding science issues and, since 1984 the American National Election Studies began to ask citizens about their assessment of federal spending on science and technology, among other policy domains. However, there is a lack of studies on public support and preferences for government spending on science, even if much research has been devoted to more general attitudes toward science and technology. This situation might reflect the fact that early studies found a relatively low level of awareness and substantive knowledge concerning science policy 
issues by the public. In fact, the seminal work by Miller (1983b) tried to link citizens' views of science to decision-making in science policy, but their results strengthened the assumption that public opinion was not, in contrast to what occurs in other policy areas, an influential element in the design of S\&T policies (Burstein 1998).

The growing interest in scientific literacy (Miller 1983a; Miller 1998), together with concerns about the limited scientific knowledge of the public or the so called public deficit model (Sturgis \& Allum 2004), has led researchers to focus more on the explanation of citizens' attitudes towards science, including public preferences for specific areas of S\&T spending. Findings suggest more positive attitudes on the part of citizens regarding areas of science related to personal wellbeing and the quality of life, while other areas of S\&T remain clearly controversial. For example, research on health or general medical issues receives strong support from citizens, while other biomedical topics (such as genetics or biotechnology) seem to meet with controversy and opposition (Nisbet 2005, Nisbet \& Goidel 2007). As a result, there is some ambivalence in citizens' attitudes and, as in other policy sectors, it becomes difficult to identify a single structure of determinants of public opinion about S\&T policy.

Research on public understanding of science has focused predominately on more general attitudes towards science with very little attention to public support for government S\&T spending. This is due to the fact that, in the area of public understanding of science, it has been largely assumed that positive attitudes towards science translate automatically into public support for more government spending on S\&T.

Research on the public understanding of science more generally has accumulated evidence about the general determinants of attitudes towards science and technology (Bauer et al. 2007; Bauer 2009). The levels of awareness, interest and substantive knowledge concerning science issues by the public have been used to account for various general attitudes towards science (Sturgis \& Allum 2004; Miller 2004), with the focus shifting from knowledge to attitudes and to a more complex analysis of the public's view of science in society. In fact, it is well known that there are significant variations in national attitudes towards science (Miller et al. 1997). For example, some studies have suggested a negative relationship between the level of development or industrialization of societies and the level of support or acceptance of science (Bauer et al. 1994; Durant et al. 2000). These findings can be referred to as the post-industrial model of PUS, 
suggesting that bellow a certain level of development there are more positive attitudes towards science, while beyond that point increasing knowledge drives more skeptical attitudes towards science. The existence of a scientific ideology or scientific myth, moreover, was found to be negatively correlated with the level of development (Bauer 2009, Sanz-Menéndez and Van Ryzin 2013).

In short, we aim to contribute to a better understanding of public support for government S\&T spending in Spain, an issue that has been only recently addressed [e.g., Muñoz et al. (2012), using Spanish data, found that stated interest is science and technology is the predominant discriminating variable, followed somewhat distantly by a rather ambiguous set of secondary factors; Muñoz and Moreno (2013) have also compared support for S\&T spending in various cities in 6 Latin American countries plus Spain; or Sanz-Menéndez and Van Ryzin (2013) have compared support for government spending in S\&T between 2006 and 2010.

While prior studies have identified some relevant variables as possible explanations for public support of S\&T spending, we would like to emphasize that there is very little available theory in this area. Because of this lack of general theories to apply to the question of public support for S\&T spending, our approach remains largely exploratory yet informed by the prior empirical studies cited above. The literature on attitudes toward public spending helps us to organise our expected relevant variables, focusing primarily on individual-level factors as determinants of support for spending (self-interest and ideological factors) and also considering the economic and policy context of the respondents' region. Even so, as the literature on attitudes toward public spending predicts, we expect to find specific patterns of citizens' preferences related to the S\&T sector, in which some of the factors (interest and participation, knowledge, attitudes towards science and institutions) identified as relevant by the literature on public opinion toward S\&T could play a role. On this basis, the empirical models constructed are based on sets of variables found relevant in previous empirical research in the field, as we discuss in detail in the next sections.

\section{1.) Demographic and socio-economic factors}

Since the early studies of public opinion, it has been assumed that citizen preferences toward taxes and government spending in different policy areas depend on, among others factors, a rational calculation of self-interest related to demographic and socioeconomic characteristics 
(Birdsall 1965; Blekesaune \& Quadagno 2003). Thus gender, age, income, level of education, employment or student situation have all be hypothesized as playing a role in shaping public support for various forms of government spending. Previous research has shown women and younger people to be more favorable toward government spending, with women particularly supportive of social programs (Sanders 1988; Carrillo and Tamayo 2011). Positive attitudes towards science have been linked with the scientific literacy of young, male and more educated people (Miller 1983b), although gender and age are sometimes not significant predictors in multivariate analyses (Hayes and Tariq 2002; Nisbet et al 2002; Sturgis and Allum 2004). Education level has been shown to be a strong predictor of support for science (Miller et al 1997), as well as positively related with support of many types of government spending, except perhaps military issues and public safety (Carrillo and Tamayo 2011). However, more educated people sometimes appear more ambivalent regarding science (Lujan and Todt 2000, Torres 2005) or with stronger positions (Pardo and Calvo 2002). In general, lower income people are more supportive of government spending, while high income people tend to oppose it (Tufte 1978), with the exception perhaps of education policy (Carrillo and Tamayo 2011).

\section{2.) Partisan factors and religious beliefs}

Attitudes to public spending are affected by people's moral values, specifically those related to economic redistribution and social justice, that means religious beliefs and political ideologies are relevant factors to take into account. Left oriented and non-Catholics have been shown to be somewhat more supportive of science and technology (Miller et al 1997). At the same time, empirical studies suggest that individuals that hold more egalitarian values are much more prone to support social spending than individuals holding more individualistic beliefs (Linos and West 2005). Religious beliefs play a role also in accounting for diverse attitudes towards governments spending, with less religious people more in favor of a stronger government role (Sanders 1988). Religious beliefs have been shown have a moderator effect on the awareness of and support for science (Nisbet 2005).

\section{3.) Interest in science and the attentive public}

General interest in and attention to an issue has been shown to be a relevant factor in accounting for support of government policy and spending as well as support for science (Nisbet et al 2002). Miller's (1983b) study of "attitudes towards science and technology issues and 
policies" used Almond's concept of "attentive public" (interested, knowledgeable and informed) and he developed the idea of a stratified model of public policy formulation to deal with the problem that science policy was not a salient topic for most of Americans. And as mentioned earlier, Muñoz et al (2012) found interest in science to be by far the strongest discriminator of those supportive of government S\&T spending in Spain.

\section{4.) Knowledge of science (scientific literacy)}

The level of substantive knowledge, or so-called scientific literacy, has been highlighted as a relevant factor explaining general public support of science. In fact, knowledge is the key element of the so called deficit model (Bauer et al 2007; Allum et al 2008). Moreover, it has been found that the role of the scientific knowledge (even if measured trough what has been called textbook knowledge) has a significant, but sometimes weak, relation with support of scientific research (Bauer et al 1994; Evans \& Durant 1994; Miller et al 1997).

\section{5.) Values and beliefs about science and technology}

Although more knowledge or information on scientific issues is associated with greater support for scientific activities (Sturgis \& Allum 2004), there are some important exceptions regarding controversial areas of research and technology, such as stem cells, embryo research, genetically modified organisms (GMOs), biotechnology, nanotechnology, or nuclear technology (Bauer 2002; Legge \& Durant 2010; Gaskel et al 1999; Gaskel et al 2004; Weldon \& Laycock 2009), where acceptance is reduced (Gupta et al 2011). Knowledgeable citizens may be ambivalent regarding many aspects of modern science; much depends on the concrete area of S\&T, on beliefs regarding the ethical and moral aspects of science, and on assessment of the pros and cons of S\&T in society.

Even if people lack the scientific knowledge to understand many of these issues, citizens use shortcuts or heuristics when forming opinions or constructing their policy preferences. The way in which people construct the cognitive devices for choosing preferences appears to be based also on the degree of confidence they have in the institutions in charge of making decisions and of managing scientific activity or in their acceptance of scientific authority (Brossard \& Nisbet 2000). If people have confidence in scientists as a profession, or believe that scientists are altruistic people (Critcheley 2008), then we would expect to see an increase in the probability of support for government S\&T spending. 


\section{6.) Political and policy attitudes}

General interest in politics and public affairs has been shown to influence attitudes towards public policies (Delli Carpini \& Keeter 1996), thus we might expect the level of understanding of the political process and of the functioning of political institutions to be a relevant factor in explaining the propensity to support S\&T issues (Sturgis \& Allum 2004). Also the level of information or knowledge about S\&T policy goals and issues (such as the perceived standing of science and technology in one's country, compared to competitor nations), could be used as a proxy for the level of interest and knowledge of the larger goals of science policy.

\section{7.) Socio-economic context}

Recently, attention has been paid to the interaction between individual factors and contextual factors that could account for differences in support for government spending (Andre $\beta$ \& Heinen, 2001). Individual beliefs vary greatly from one society to another, according to various institutional factors and social structures. Different factors — such as the level of income, the different social structures, of varying expenditure levels in a policy area—may affect attitudes toward public spending. A high level of development of a country (or a region) and a high income level tend to moderate the demands of citizens for public intervention and to condition the preferences toward either materialist or postmaterialist policies (Inglehart 1990).

Researchers have found a significant variation in national attitudes towards science. Comparisons among countries in Europe suggests an inverse U shaped function connecting the level of development and industrialization of societies and the level of support or acceptance of science (Bauer et al 1994; Durant et al 2000). Most developed societies have become more cautious regarding some side effects of S\&T (Gaskel et al 1999). Recent research has focused on the effect that the crisis has on public support for government spending in S\&T (Sanz-Menéndez and van Ryzin 2013). Additionally, the relationship between citizens' preferences toward public spending and the responsiveness of policymakers are relevant (Monroe 1979; Page and Shapiro 1992). There is a wide consensus that public opinion matters (Burnstein 1998) and that there is a clear association between policy budgets and the spending preferences expressed by citizens (Soroka and Wlezien 2010). 


\section{Data and Methods}

To test these explanations empirically, we use data from a comprehensive survey of public attitudes toward science and technology in Spain conducted in 2006 by the Spanish Center for Sociological Research (Centro de Investigaciones Sociológicas [CIS] 2006/2652) in collaboration with the Fundación Española para la Ciencia y la Tecnología-FECYT ${ }^{1}$. The survey involved in-person household interviews of 7,056 randomly selected adult residents of the 17 regions of Spain, ranging from 308 thousand to 8 million inhabitants. The survey design, however, called for approximately equal-size random samples from each region, resulting in disproportionate probabilities of selection by region. Thus, sampling weights were constructed (representing the inverse of the probability of selection) and applied in all analyses reported here $^{2}$. The survey asked a wide range of questions about interest in, participation in, knowledge of, and attitudes toward S\&T, as well as basic social, economic, and political characteristics of respondents. Based on the hypotheses discussed above, we selected the following measures as our main dependent and independent variables.

\section{1.) Dependent variables}

Measuring public support for government spending in any policy area is a complex issue, reflecting a mix of preferences regarding policy issues, opinions regarding assignment of responsibility across levels of government (as well as the public or private sectors), trust in government management of the budget, and more general attitudes toward the proper role of government in the economy and society. Thus, measuring support for government S\&T spending may reflect several of these dimensions of public opinion. We have identified two dimensions that could be measured in the survey that are distinct but complementary.

3.1.1.) $S \& T$ as a priority for government spending. The first dimension is the relative priority for S\&T spending, when citizens assign it in comparison with other areas of potential government allocation of resources. Choosing S\&T indicates a citizens' opinion regarding a general role for government in this spending area. It measures the priority or interest of citizens

\footnotetext{
${ }^{1}$ Data, general results and questionnaire are available at the CIS web page: http://www.cis.es/cis/opencm/ES/2 bancodatos/estudios/ver.jsp?estudio=7800\&cuestionario=9014\&muestra=14225 (Last access in 24 March 2013).

${ }^{2}$ Stata 11 was used for the analysis, including the procedures for probability weights.
} 
with regards to this area (having in mind the alternative use of limited government money). This measure comes from an early question in the survey in which interviewers first asked respondents to "imagine for a moment that you could decide where to spend public funds," and then showed respondents a card with the following sectors listed: "public works, public safety, transportation, science and technology, environmental protection, defense, justice, culture, and sports." ${ }^{3}$ Respondent could choose up to three of these sectors for public spending. Thus, we created a dummy variable that indicates respondents who chose "science and technology" as one of their choices on the list. Interestingly, only about 20 percent of respondents selected science and technology as a priority area for public spending, as shown in Table 1 (weighted results).

3.1.2.) Support forS\&T spending by national and regional governments. The second dimension is the explicitly stated support for government (s) spending in S\&T. It is the traditional way of approaching the issues and combines an actual assessment of the amount of resources allocated for S\&T and opposition to budget cuts. It means that respondents need to have and informed opinion on the current situation and level of government spending levels and support for S\&T. Specifically, respondents were asked a series of more direct questions about their general support for science and technology spending by both central and regional governments (with the relevant responses starred and in bold, as explained shortly):

- Do you believe the central government dedicates too much, the right amount, or *too little resources to science and technology?

- Do you believe the regional government dedicates too much, the right amount, or *too little resources to science and technology?

- Do you favor, or *oppose, a reduction in spending on science and technology by the central government?

- Do you favor, or *oppose, a reduction in spending on science and technology by the regional government?

We created a summative index of these questions by counting up the starred $(*)$ responses across all four questions, from 0 (none of the starred responses chosen) to 4 (all four of the

\footnotetext{
${ }^{3}$ The list of policies offered in this question deliberately excluded health, education and pensions because these programs enjoy a wide popularity among Spanish citizens and are known to be selected as the first choices for public spending (Calzada and Del Pino, 2011); two of the authors were involved in the design of the questionnaire.
} 
starred responses chosen). To facilitate interpretation, we then rescaled the variable from 0 to 100 (by multiplying by 25). Thus, the variable has a mean of 58, as shown in Table 1 (weighted results), and provides a measure of the degree to which respondents express support for increased government spending on $\mathrm{S} \& \mathrm{~T}^{4}$.

We use two different dependent variables because, although similarly focused on respondents' preferences for government spending on S\&T, they measure such preferences in two distinct but complementary ways. The correlation between the two variables is only $r=.18$, suggesting that they do in fact measure different dimensions of preference or support. Regarding their complementarity, the dummy variable for selecting S\&T from among other possible areas of government spending is a more general measure of preference or priority for government intervention in the field of S\&T. Moreover, this question appeared early in the interview and thus respondents were not prompted in any way to consider S\&T over other policy areas. In contrast, the 0-100 index comes from a later set of questions in the interview that explicitly asked respondents to express their views about the scope or intensity of government intervention (more or less public spending) on S\&T. In this sense, although both indicators measure citizens' support for government spending on S\&T, we believe they are complementary and together provide insight on the complexities of public support for S\&T policies.

\section{2.) Independent variables}

We conceptualize and analyze our independent variables in blocks, following the hypotheses discussed above, including: demographic and socioeconomic characteristics, ideology, interest and participation in science, knowledge of science, values and beliefs about science, policy attitudes, and regional context. Table 1 presents the definition and descriptive statistics for each of the variables.

\section{-Table 1 ABOUT HERE-}

The demographic variables include sex, age in years, and an ordinal measure of education. The socioeconomic measures include income in Euros and dummy variables for being employed

\footnotetext{
${ }^{4}$ We also ran regression (probit) models separately for each of these questions, coded as individual dummy variables, but the results (not reported here) were substantively similar to those for the models using the aggregated 0-100 measure as a dependent variable. Indeed, the correlations of the aggregate measure with each of the individual questions are all .80 or higher.
} 
and a student. And the ideology variables include a dummy variable for practicing Catholics, as well as a measure of political ideology on a 1-10 (left-right) scale.

Interest and participation in science was measured by two variables. The first is a direct selfreported level of interest in science on a 1-5 scale (very uninterested to very interested). The other measure comes from a series of yes-no questions that asked respondents if they attended various activities or events in the last year, including the theater, movies, art museums, and also science and technology museums as well as Science Week in Spain (a national series of events dedicated to the promotion of interest in science). Those who visited a science museum or attended a Science Week event were coded as 1 , the rest were coded as 0 .

We use two measures of knowledge of science. The first is a self-reported level of being informed about science on a 1-5 scale (from very uninformed to very informed). The second comes from a series of 10 true-false questions on a card that tested the respondent's actual knowledge of scientific facts ${ }^{5}$. Thus, the variable ranges from 0 (no correct answers) to 10 (all 10 questions answered correctly) and provides a proxy of knowledge of scientific facts. We also include a dummy variable for those with a university degree in science.

Values and beliefs about science are addressed from distinct measures. The first is a summated scale of trust or confidence in the work of professional scientists, engineers, and medical doctors. For each of these three professions, respondents indicated on a 1-5 scale whether they valued their work very little to a great deal (thus the scale ranges from 3-15). Next we constructed an index of respondents' general outlook on the benefits of science composed of the sum of two agree-disagree statements: Science and technology are the ultimate expression of prosperity in our society; Science and technology serve above all to resolve problems. In addition, we include in the model a dummy variable from a summary question that asked respondents if, on balance, the positive aspects of science outweigh the negative. Finally, we included a dummy variable that indicated whether respondents believe scientists are motivated primarily by the search for new knowledge and the solution of problems (coded 1 for altruistic motives) or by prestige, money, a flexible schedule, good working conditions, or inertia (all coded 0 for more selfish motives).

\footnotetext{
${ }^{5}$ The card displayed statements such as "the sun rotates around the earth" (false) or "the oxygen we breath comes from plants" (true), following the "textbook" knowledge model. The questionnaire is publicly available (see note 1).
} 
Respondents' interest and attitudes toward public policy are relevant factors to take into account. The first is a 5-point measure of stated interest in politics and policy, ranging from very uninterested to very interested. The next is a dummy variable from a question that asked about Spain's position, relative to other European countries, with respect to research in S\&T. Those who felt Spain was behind other European countries were coded 1, while those who felt Spain was at the same level or more advanced (or did not know) were coded 0 . We use this variable as a proxy for awareness of the science policy pressures on Spain relative to the rest of Europe and the policy targets.

Finally, we provide the individual response with a regional context. There are 17 regions in Spain which vary a great deal in social, economic, and policy context, and we have the opportunity to control for the effects of different regional variables related to income, position of $\mathrm{S} \& \mathrm{~T}$ in the economy, and the role of S\&T in regional government budgets. We chose four regional variables for inclusion in the model: GDP per capita, as a measure of the general economic prosperity of the region; research and development as a percent of regional GDP, as measure of the share of the regional economy involved in S\&T; percent of the 18-24 population enrolled in university, as a measure of relevance of the knowledge society; and percent of the regional government's budget devoted to S\&T, as a measure of the regional government policy commitment. All regional data come from official statistical sources.

Again, the definitions and descriptive statistics for all of these analytical variables can be found in Table 1. It should be noted that, to reduce missing data in the multivariate models, substitution of the mean or median (for ordinal variables) was employed for selected variables with high levels of don't know or no answer (Bauer 1996; Pardo and Calvo 2002). Although the level of missing data in the multivariate models was less than 10 percent, the substitution of missing data provides for more consistency in the size of the sample across analytical models and did not influence the substantive results.

\section{Analysis and Results}

In our analysis, we first use probit regression to look the predictors of the choice to select S\&T spending as a priority for government (a dichotomous variable). Next, we use ordinary least squares (OLS) regression to examine the predictors of explicitly stated support for government spending on S\&T, as measure by our 0-100 index (explained above). All of the models are 
estimated using survey weights and clustered (by region) robust standard errors. In both the probit and OLS models, we enter each block of variables (corresponding to the sets of hypotheses presented in section 2) in a cumulative fashion to show how the results change (or remain stable), depending on the inclusion of other variables, allowing us to probe for possible evidence of mediation. The ordering of blocks reflects the presumed causal order of variables. We maintained non-significant variables because they were theoretically relevant and to make the models more directly comparable, in terms of specification.

-Table 2 ABOUT HERE-

Table 2 shows the results of our probit models predicting the proportion of respondents who selected S\&T as a preferred area for government spending, with the coefficients shown in the form of a change in probability of $\mathrm{Y}=1$ (for a one unit increase in $\mathrm{X}$, with the other independent variables fixed at their means) ${ }^{6}$. As the basic demographic Model 1 in Table 2 shows, females are less likely than males to select science and technology as a preferred area for government spending. Respondents with higher levels of education are more likely to select S\&T, as are those who are employed and those who are students. Model 2 adds the two indicators of ideology, only one of which is significant: respondents on the right politically are less likely to select science and technology as a preferred area for government spending. Both models explain only about 6 percent of variance in the dependent variable (pseudo R-squared).

Model 3 adds the two measures of interest and participation in science, both of which are strong and statistically significant predictors; explained variance more than doubles from the previous models, to nearly 13 percent. The coefficients indicate that respondents who express an explicit interest in science as well as those who report being actively interested (by attending science museums and events) are much more likely to choose S\&T as a preferred area for government spending. It should be noted that the coefficient on gender is no longer significant in this model, suggesting that interest in science is a mediator of the gender effect observed in the previous models. Similarly, interest in science also appears to be a mediator of the student effect, which also disappears in this model.

\footnotetext{
${ }^{6}$ Based on the dprobit command in Stata 11.
} 
Model 4 adds the indicators of knowledge of science, all of which are statistically significant predictors. Respondents who say they are informed about science, those who score objectively higher on the 10-item battery of science knowledge questions, and those with a science degree are all more likely to select S\&T as a preferred area for government spending. Explained variance rises a bit to just under 14 percent in this model.

The next model, Model 5, includes the addition of values and beliefs about science, two of which turn out to be significant although not especially strong predictors. Respondents who believe that the benefits of science generally outweigh the dangers, and those who believe that scientists are motivated primarily by altruistic purposes, are more likely to select S\&T as a preferred area for government spending. Moving on to Model 6, neither of the two policy attitudes - interest in politics/policy and holding the view that Spain is behind the EU average in S\&T - turn out to be important predictors. Explained variance remains a little over 14 percent in both models.

Finally, Model 7 includes the regional context variables, two of which are significant. As expected, respondents are more likely to choose S\&T as a preferred area for government spending in regions in which the regional government dedicates a greater share of its resources to S\&T. But respondents in regions in which a greater percentage of young adults are enrolled in university turn out to be less likely to select S\&T as a spending area. This final model, which includes all of the predictors, explains nearly 15 percent of variance in the dependent variable.

-Table 3 ABOUR HERE-

Table 3 presents the results of our ordinary least squares (OLS) models predicting the degree to which respondents express support for government spending on S\&T, as measure by our 0100 index (explained above). Although expressed support for science and technology spending by government would seem very similar to choosing $\mathrm{S} \& \mathrm{~T}$ as a preferred area for government spending (from a list of other government spending areas), as noted earlier these two dependent variables actually measure different dimensions of public preference or support. Thus, although we would expect some similarities to the previous results, the array of significant predictors is likely to be different in these models.

Model 1 of Table 3 includes the basic demographic and socioeconomic predictors. Similar to the previous set of results, females are less likely than men to express support for government 
spending on S\&T. And respondents with higher levels of education are more likely to express such support. Model 2 adds the ideology variables, neither of which turn out to be significant predictors. In contrast to the previous results, political ideology is not related to express support for strengthening S\&T spending by government. The explained variance (R-squared) in both models is about 9 percent.

Model 3 adds in the two measures of interest and participation in science, and consistent with the previous findings both are significant and strong predictors. Specifically, respondents with a self-stated interest in science and those with an active participation are much more likely to express support for government spending on S\&T. In contrast to the previous results, however, interest does not fully mediate the gender effect.

Model 4 adds the measures of knowledge of science, and only objectively assessed knowledge of science (using the 10 factual questions) is positively related to support for S\&T spending. Having a science degree has a negative association. And being informed, as selfreported, is unrelated to support. The explained variance rises to 15 percent. With both interest and knowledge of science now in the model, the gender effect diminishes below statistical significance. This suggests that, in the case of expressed support for S\&T spending, knowledge of science (along with interest in science) mediates the gender difference in support.

Model 5 adds the four measures of values and beliefs, three of which are statistically significant predictors. Respondents with a generally positive outlook on the benefits of science, those who believe the benefits outweigh the harms, and those who believe scientists have altruistic motives are all more likely to express support for government spending on S\&T; the explained variance increase to nearly 18 percent in this model.

Model 6 adds policy attitudes, and the striking result here is a large effect for viewing Spain as behind the EU in S\&T. Specifically, respondents who see Spain as lagging the EU are 12 points more likely to support government spending on science and technology. Curiously, this variable was not a significant predictor at all in the previous models of S\&T as a spending priority (Table 2). General interest in politics and policy is not associated with such support, as before. The explained variance rises to over 20 percent.

Finally, Model 7 adds in the regional context variables, only one of which is statistically significant. Respondents in regions in which the regional governments devotes a greater share of 
the budget to S\&T express less, rather than more, support for government spending on science and technology. None of the other regional variables are significant, and the explained variance goes up a bit to 21 percent.

\section{Discussion and conclusions}

Our study has examined the predictors of public support for government S\&T spending. Due to the limited scope of the few studies on this specific topic, we have constructed our hypotheses resorting to two well-established streams of research and we contend that support for S\&T can be explained by some of the same factors that explain general attitudes towards science and account for support for other public policies. Our results help to shed light on some of the factors that may explain public support for S\&T spending and can also contribute to these two strands of literature.

Firstly, our findings bear on the debate on the determinants of public attitudes toward S\&T spending. Only to a certain extent can it still be assumed that citizens who have positive attitudes toward S\&T are always more supportive of spending public resources on the sector. Comparing our two models (Tables 2 and 3), there are several variables which are clear and consistent predictors of the support for both science and government S\&T spending: respondent's educational level, interest and knowledge in S\&T, and having positive values and views of science. Interestingly, the role of other explanatory variables varies with the way support for public spending on S\&T is measured. Having a science degree, being a student, and living in a region with a higher public budget allocated to science and technology all show varying effects, depending on the model; on the one hand, those citizens show a preference for spending on these policies vis-à-vis others but, on the other, they are less supportive of additional public spending (or more flexible with possible budget reductions) in science and technology. This finding is consistent with previous research showing that more informed and knowledgeable people have stronger opinions (Pardo \& Calvo 2002, 2004) and their attitudes could appears as ambivalent because of the complexity of the assessment as an interaction between information and values. Additionally, the explanation could be that these citizens might be more aware of the efforts that governments have already made in the sector in recent years and thus might believe that spending is sufficient for the moment; as we discussed earlier, citizens are able to adjust their preferences in response to changes in budget allocations for different policies. This finding could 
also be connected with the so called thermostat effect: when spending reaches a threshold, citizens' support for additional public spending may moderate in response.

Interestingly, political ideology and religious beliefs are only relevant to explaining S\&T as a priority government spending area, but not when citizens are asked directly about their support for S\&T government intervention as a decision to allocate more resources. In this case, being more knowledgeable and informed appears to have a negative effect on support, in the same way that in more develop countries in the EU support for science appears more ambiguous. Similarly, in Spanish regions with higher budget for S\&T people do not support increases in S\&T budgets. ${ }^{7}$

Several variables (level of education, largely ideology, interest and knowledge in S\&T, and having positive values and views of science) emerged in our study as having some potential to explain citizens' support for science and technology spending. To start with socio-demographic factors our results confirm that those people with higher levels of education are more likely to select S\&T policy as a priority and to support increased public spending in this area. Although educated people sometimes appear ambivalent concerning science and often have stronger attitudes (Pardo \& Calvo 2002), more educated individuals seem more aware of the importance of public expenditure in this policy area (Miller et al 1997), as well as related policy areas such as education or culture (Carrillo and Tamayo 2011). On the other hand, comparing Tables 2 and 3 , our results confirm that age or level of household income are not significant. Although the basic demographic models indicate that women are generally less supportive of spending on S\&T than men, when other variables are included in the model sex was no longer significant. This suggests that the gender difference in support for spending on S\&T is perhaps due to sex differences in other variables (Hayes \& Tariq 2002), such as interest in or knowledge of science. Our results show that citizens on the political left and those with weaker religious beliefs are more supportive of the choice of S\&T for more government spending ${ }^{8}$.

\footnotetext{
${ }^{7}$ In any case, we must be very cautious with these results since we only have 17 regions and the heterogeneity is less than between EU countries. Moreover, additional observations, or data at different points of time, would be needed to refine and qualify these findings. Regarding the other two variables related to the prosperity of the region, GDP per capita and share of the regional economy involved in S\&T, they do not have significant effects.

${ }^{8}$ Perhaps those on the political right were less likely to select S\&T because the list of choices offered in the survey included policies associated with the usual preferences of conservatives, in particular security, justice, and public works. For citizens on the left, however, the list offered in the survey did not include health, education and pensions, among others, which are often preferences associated with progressives; thus, the significant effect of political
} 
Interest and participation have a significant effect on public support for government S\&T spending. The coefficients of both the probit and OLS models are highly significant, even when controlling for other variables and the magnitude of the effect is noteworthy. Thus, our findings are consistent with those of Muñoz et al. (2012) who also found interest in science to be a strong predictor of support for government S\&T spending, although in our study interest is just one of several important predictors.

Regarding citizens' knowledge about science, respondents cognizant of science issues were more likely to select S\&T as their preferred area for public spending. In contrast to the effect of having a degree that we mentioned above, the effect of the "textbook" knowledge of science (the 1-10 index of knowing scientific facts), which is not significant in the choice of S\&T spending over other areas, become significant as a predictor of expressed support for government S\&T spending. Regarding values and beliefs, more positive values and beliefs about science do indeed have a positive effect on support for government S\&T spending. But again citizens were asked about their support of public spending on S\&T in general, as well as their values and beliefs about science in general, and not asked about specific research programs, which could possibly result in more ambivalent positions. It is interesting that science values and beliefs produce effects in the same directions in both models (probit and OLS), with most of the effects appearing significant except for one (trust in science professionals). Thus, those that believe that the benefits of S\&T are positive both select science and technology as a priority area and explicitly support increased spending in this policy area.

Interest in politics and policy issues did not have a significant effect on support for S\&T spending. However, seeing Spain as lagging behind other countries in the EU in terms of S\&T was a significant and strong predictor of expressed support for increases in government S\&T spending, highlighting again the relationship between knowledge (in this case of a policy situation) and the general demand for increasing government efforts to cope with the problem. The connection disappears, however, when the issue becomes a matter of choosing and selecting S\&T policy over other areas of government spending.

ideology may be somewhat of an artefact of the design of the questionnaire in a way that enhanced the visibility of science and technology policy. 
Secondly, our findings also touch on the debates within the literature on citizens' attitudes toward government spending which have focused particularly on social welfare policies. Regarding social policies, socioeconomic interest and ideological variables have been established as the main determinants of citizens' support. Concerning S\&T policies, some other variables turn out to be more important. Our results suggest the usefulness of considering additional variables regarding social welfare policies such as measures of knowledge of this kind of policy sector (health or education, for example) or the perception of the relative position of the country with respect to competitor nations in the specific policy domain.

There are, of course, a number of caveats and limitations to our study that should be pointed out. To begin with, our findings, based on data from Spain, may not necessarily generalize to other countries, although that is a question for future empirical research in other national contexts regarding support for government expenditure in S\&T. Moreover, the survey was conducted during the height of a period of rapid economic expansion and a few years before the onset of the European economic and debt crisis. Certainly, attitudes toward science and public spending in a time of crisis and austerity may be different than those expressed in a time of prosperity. Moreover, a recent paper by Sanz-Menéndez and Van Ryzin (2013) suggests that interest in and support for science and technology may have even increased after the crisis, perhaps because people look to S\&T policy and spending as a way to grow new industries and escape an economic downturn. In any event, given the profound changes in the Spanish economy and society stemming from the crisis, it remains to be seen if the predictors we have identified here continue to be important over time.

Another, methodological limitation is that the questions used to construct the index of expressed support for S\&T spending were placed later in the interview, so that respondents were well aware that it was a survey about science and technology and had time to reflect on the issue. In other words, the measure of expressed support for S\&T spending may well suffer from a social desirability bias, which may explain some of the differences we found across models. Also the way of measuring the choice of support of S\&T expenditure could be considered biased, because it excluded key areas of social expenditure. When confronted with more pressing priorities such as jobs and cuts in social policies, citizens may well change their priorities in terms of government action. The priority assigned to welfare policies, especially those related with unemployment protection and the fight against social exclusion, certainly would increase in 
times of crisis. In contrast, other policies, such are security, defense or environmental protection, tend to see a reduction in the priority attributed by citizens and in the assessment regarding the allocation of government resources. These patterns are also present in the Spanish situation (Calzada and Del Pino 2013).

A more fundamental methodological limitation is that we used measures from a crosssectional survey in which the causal order of many of the variables remains uncertain. But we would argue that the background demographic and socioeconomic factors, ideology, interest and knowledge of science, and even values and beliefs about science are likely to have been established relatively early in a person's life and thus can be viewed as valid antecedents of support for government S\&T spending. Still, it is possible that there remain some omitted variables that are common causes of both general attitudes toward science and specific preferences for government S\&T spending that may be biasing our results (Remler and Van Ryzin 2011). Thus, our results should be viewed as evidence of statistical associations that suggest ideas about possible causal explanations, rather than a firm demonstration of causation as such.

Future research might help to further account for support for S\&T policies. The data collection referred to a time in which growth and positive economic conditions favoured the general perception of a bigger role for government expenditure; the impact of the crisis could have changed the external conditions of public opinion in profound ways. For example, the crisis has been associated with a reduction of public support for environmental policies (Scruggs and Benegal 2012), even if the effects of the crisis on expenditure preferences and support for S\&T seem to suggest an increase in support (Sanz-Menéndez and Van Ryzin 2013). Thus, it would be useful to reflect on several issues and improve the research design through various means: It would be useful to include several countries and regions in our analysis, with different economic and cultural features, as well as different policy trajectories in science and technology. At the same time, more observations of the same country, at different points in time, would be needed to confirm some of our findings, for example, regarding the thermostat effect (that is to say, the relationship between the co-variation of public budgets and citizens' preferences about public spending on S\&T). Moreover, a larger series of data would allow us to observe differences between contexts of economic prosperity and crisis. In times of crisis, for example, citizens preferences usually alter, prioritizing welfare policies (health, education and pensions) and 
weakening support for public spending in other policy areas (Del Pino et al. 2011). Finally, our findings could have been different had we asked for spending preferences regarding specific research programmes or areas inside S\&T. Further research should concentrate on support for these programs, which are sometimes more controversial in public discussion.

\section{Funding}

This work was supported by the Spanish National R\&D Plan (Ministry of Science and Innovation [grant CS0-2008-03100] and Ministry of Economic Affairs and Competitiveness [grant CS0-2011- CSO201129431] and the 2011 CSIC-IPP Short Term Visiting Fellows Program (IPP-2011-VF-03) that partially funded a short term visit of Gregg G. Van Ryzin to Madrid.

\section{Acknowledgements}

An early draft of this paper was presented at Eu-SPRI Annual Conference 2012 held in Karlsruhe 12-13 June; we thank participants for the comments and criticisms and to Jose Luis Lujan and Jesus Rey and the Science and Public Policy reviewers for comments and suggestions. We also thank the Centro de Investigaciones Sociológicas (CIS) and the Fundación Española para la Ciencia y Tecnología (FECYT) for providing us access to the data of the Encuesta de Percepción Pública de la Ciencia 2006.

\section{References}

Allum, N.; Sturgis, P.; Tabourazi, D.; Brunton-Smith, I. (2008) 'Science knowledge and attitudes across cultures: a meta-analysis', Public Understanding of Science, 17(1): 35-54.

Anichini, G.; de Cheveigne S. (2012) 'Overview of research related to science in society in Europe', Science and Public Policy, 39 (6): 701-709

Andreß, H.-J.; Heinen, T. (2001) 'Four World of Welfare State Attitudes? A Comparison of Germany, Norway and United States', European Sociological Review, 17(4): 337-356.

Bauer, M. (1996) 'Socio-demographic correlates of DK-responses in knowledge surveys: self-attributed ignorance of science'. Social Science Information, 35(1): 39-68.

Bauer, M. W. (2002) 'Controversial medical and agri-food biotechnology: A cultivation analysis', Public Understanding of Science, 11(2): 93-111.

Bauer, M. W. (2009) 'The Evolution of Public Understanding of Science--Discourse and Comparative Evidence', Science, Technology \& Society, 14(2): 221-240.

Bauer, M. W.; Allum, N.; Miller, S. (2007) 'What can we learn from 25 years of PUS survey research? Liberating and expanding the agenda', Public Understanding of Science, 16(1): 79-95.

Bauer, M.; Durant, J.; Evans, G. (1994) 'European Public Perceptions of Science', International Journal of Public Opinion Research, 6(2): 163-186. 
Birdsall, W. C. (1995) 'A Study of Demand for Public Goods', in R. A. Musgrave (comp.) Essays in Fiscal Federalism. Washington: The Brookings Institutions, pp. 235-294.

Blekesaune, M.; Quadagno, J. (2003) 'Public Attitudes toward Welfare State Policies: A Comparative Analysis of 24 Nations", European Sociological Review, 19 (5): 415-427.

Brossard, D.; Nisbet, M.C. (2007) 'Deference to scientific authority among a low information public: understanding U.S. Opinions on agricultural Biotechnology", International Journal of Public Opinion Research, 19 (1) 24-52.

Burstein, P. (1998) 'Bringing the Public Back In: Should Sociologists Consider the Impact of Public Opinion on Public Policy?', Social Forces 77 (1): 27-62.Burstein, P. (2003) 'The Impact of Public Opinion on Public Policy: A Review and an Agenda'. Political Research Quarterly, 56 (1): 29-40.

Calzada, I.; del Pino, E. (2011) 'Are Spaniards Different? European Convergence and Regional Divergence in the Evaluation of the Welfare State', in Guillén, A.M.; León, M. (eds.), The Spanish Welfare State in European Context. Farnham: Ashgate, pp. 139-65.

Calzada, I.; Del Pino, E. (2013) 'Algo cambia, algo permanece: los españoles ante el gasto público, el gasto social y los impuestos durante la crisis (2008-2012)', Revista Presupuesto y Gasto Publico, 71: 165-186.

Carrillo, E.; Tamayo, M. (2011) 'La formación de las preferencias de gasto público: Un análisis comparado por políticas públicas', Frontera Norte, 23, 25, 193-230.

Critchley, C. R. (2008) 'Public opinion and trust in scientists: the role of the research context, and the perceived motivation of stem cell researchers', Public Understanding of Science, 17(3): 309-327.

Delli Carpini, M. X.; Keeter, S. (1996) What Americans know about politics and why it matters, New Haven, Yale University Press.

Del Pino, E., Díaz, J. M.; Palop, P. (2011) La administración a juicio de los ciudadanos: actitudes hacia el gasto público. Madrid: AEVAL http:/www.aeval.es/comun/pdf/calidad/Informe_Percepcion_2011.pdf. (accessed on March 23rd 2013)

Durant, J., Bauer, M., Gaskell, G., Midden, C., Liakopoulos, M.; Scholten, L. (2000) 'Two Cultures of Public Understanding of Science and Technology in Europe'. In Dierkes, M.; von Grote, C. (eds.) Between Understanding and Trust. The Public, Science and Technology, London: Routledge (reprint 2003). pp.131156.

Evans, G.; Durant, J. (1994). 'The relationships between knowledge and attitudes in the public understanding of science in Britain', Public Understanding of Science, 4(1), 57-74.

Free, Ll. A.; Cantril, H. (1967) The Policial Beliefs of Americans: A Study of Public Opinion. New Brunswick, N. J.: Rutgerts University Press.

Gaskell, G., Allum, N. Wagner, W.; Kronberger, N. Torgersen, H.; Hampel, J., Bardes, J. (2004) ‘GM Foods and the Misperception of Risk Perception', Risk Analysis, 24 (1): 185-194.

Gaskell, G.; Bauer, M.W., Durant, M.; Allum, N.C. (1999) 'World apart? The reception of genetically modified foods in Europe and in U.S.', Science, 285, 384-387.

Gupta, N.; Fischer, A.R.H.; Frewer, L.J. (2012) 'Socio-psychological determinants of public acceptance of technologies: a review', Public Understanding of Science, 21(7): 782.795.

Hayes, B.C. \& Tariq, V.N. (2002) 'Gender differences in scientific knowledge and attitudes towards science: a comparatives study of four Anglo-American nations', Public Understanding of Science, 9 (4), 433-447.

Inglehart, R. (1990) Culture shift in advanced industrial society, Princeton N. J.: Princeton University Press. 
Jacoby, W. G. (1994) 'Public Attitudes toward Government Spending', American Journal of Political Science, 38 (2): 336-361.

Jacoby, W. G. (2000) 'Issue Framing and Public Opinion on Government Spending', American Journal of Political Science, 44, 4, 750-767.

Legge Jr., J. S.; Durant, R. F. (2010) 'Public Opinion, Risk Assessment, and Biotechnology: Lessons from Attitudes toward Genetically Modified Foods in the European Union'. Review of Policy Research, 27 (1): $59-76$.

Linos, K., West, M. (2003) 'Self- interest, Social Beliefs and Attitudes to the Redistribution', European Sociological Review, 19 (4): 393-409.

Lujan, J. L.; Todt, O. (2000). 'Perceptions, Attitudes and ethical Valuations: the Ambivalence of the Public Image of Biotechnology in Spain', Public Understanding of Science, 9 (4): 383-392.

Miller, J. D. (1983a) 'Scientific Literacy: A Conceptual and Empirical Review', Daedalus, 112 (2): 29-48.

Miller, J. D. (1983b) The American people and science policy. The role of public attitudes in the policy process. New York: Pergamon Press.

Miller, J. D. (1998) 'The measurement of civic scientific literacy', Public Understanding of Science, 7 (3): 203-223.

Miller, J.D. (2004) 'Public Understanding of, and Attitudes toward, Scientific Research: What we know and What we need to know', Public Understanding of Science, 13 (3): 273-294.

Miller, J.D., Pardo, R.; Niwa, F. (1997) Public perceptions of science and technology. A comparative study of the European Union, the United States, Japan and Canada. Madrid: Fundación BBV

Monroe, A. D. (1979) 'Consistency between Public Preferences and National Policy Decisions', American Politics Research, 7 (1): 3-19.

Muñoz, A.; Moreno, C.; Luján, J. L. (2012) 'Who is willing to pay for science? On the relationship public perceptions of science and the attitude to public funding of science', Public Understanding of Science, 21 (2): 242-253.

Muñoz, A.; Moreno, C.(2013) 'Actitud hacia la financiación pública de la ciencia. Un estudio comparativo en el contexto latinoamericano', Sistema 230: 55-73.

Nelson, R.R.; Roemer P.M. (1996) ‘Science, Economic Growth and Public Policy', Challenge, March-April 1996: 9-21

Nisbet M. C. (2005) 'The Competition for Worldviews: Values, Information, and Public Support for Stem Cell Research', International Journal of Public Opinion Research, 17 (1): 90-112.

Nisbet, M. C.; Goidel, R. K. (2007) 'Understanding citizen perceptions of science controversy: bridging the ethnographic survey research divide', Public Understanding of Science, 16 (4): 421-440.

Nisbet, M. C.; Scheufele, D. A.; Shanahan, J.; Moy, P.; Brossard, D.; Lewenstein, B. V. (2002) 'Knowledge, Reservations, or Promise?: A Media Effects Model for Public Perceptions of Science and Technology', Communication Research, 29 (5): 584-608.

NSB-NSF (2010) Science and Engineering Indicators 2010. Washington DC: US NSF.

OECD (2011) Main Science and Technology Indicators 2011-I, Paris: OECD

Page, B. I.; Shapiro, R. Y. (1992) The Rational Public: Fifty Years of Trends in Americans' Policy Preferences. Chicago: University of Chicago Press. 
Pardo, R.; Calvo, F. (2002). 'Attitudes toward science among the European public: a methodological analysis', Public Understanding of Science, 11 (2): 155-195.

Pardo, R.; Calvo, F (2004). 'The Cognitive Dimension of Public Perceptions of Science: Methodological Issues', Public Understanding of Science, 13 (3): 203-227.

Prpic, K. (2011) 'Science, the public, and social elites: How the general public, scientists, top politicians and managers perceive science', Public Understanding of Science, 20 (6): 733-750.

Remler, D. K.; Van Ryzin, G. G. (2011) Research Methods in Practice. Los Angeles: SAGE Publications.

Sanders, A. (1988) 'Rationality, self.interes, and Public Attitudes on Public Spending', Social Sciences Quarterly, 69 (2): 311-324.

Sanz-Menéndez, L.; Van Ryzin, G. (2013) 'Economic crisis and public attitudes toward science: A study of regional differences in Spain', Public Understanding of Science (forthcoming), DOI: $10.1177 / 0963662513489790$.

Scruggs, L.; Benegal, S. (2012) 'Declining public concern about climate change: Can we blame the great recession?', Global Environmental Change, 22 (2): 505-515.

Sears, D. O.; Citrin, J. (1985) Tax Revolt: Something for Nothing in California. Cambrigde: Havard University Press.

Sheehan, J.; Wyckoff, A. (2003) 'Targeting R\&D: Economic and Policy Implications of Increasing R\&D Spending', OECD Science, Technology and Industry Working Papers, 2003/08, http://dx.doi.org/10.1787/072772055603 (accessed on November 2012).

Soroka, S. N.; Wlezein, Ch. (2010) Degrees of Democracy. Politcs, Public Opinon, and Policy. Cambridge: Cambridge University Press.

Sturgis, P.; Allum, N. (2004) 'Science in Society: Re-Evaluating the Deficit Model of Public Attitudes', Public Understanding of Science, 13 (1), 55-74.

Svallfors, S. (2003) 'Welfare Regimes and Welfare Opinions: A Comparison of Eight Western Countries', Social Indicators Research, 64: 495-520.

Torres Albero, C. (2005) 'La ambivalencia ante la ciencia y la tecnología', Revista Internacional de Sociología, 42: 9-38.

Tufte, E. R. (1980) Political Control of the Economy. Princeton (NJ): Princeton University Press.

Weldon, S.; Laycock, D. (2009) 'Public opinion and biotechnological innovation'. Policy and Society, 28 315-325. 
TABLE 1. Decriptive statistics

\begin{tabular}{|c|c|c|c|c|c|}
\hline & $\mathbf{N}$ & Min & Max & Mean & SE \\
\hline \multicolumn{6}{|l|}{ Dependent variables } \\
\hline Selecting S\&T for public spending ( $1=y e s, 0=n o)$ & 7056 & 0 & 1 & 0,197 & 0,0061 \\
\hline \multicolumn{6}{|l|}{ Demographic and socioeconomic characteristics } \\
\hline Female $(1=y e s, 0=$ no $)$ & 7056 & 0 & 1 & 0,513 & 0,0076 \\
\hline Age (in years) & 7056 & 15 & 98 & 44,729 & 0,2796 \\
\hline Income of household (in 000 Euros) & 7056 & 10 & 70 & 18,806 & 0,1158 \\
\hline Respondent is employed ( $1=y e s, 0=$ no) & 7056 & 0 & 1 & 0,487 & 0,0075 \\
\hline Respondent is a student ( $1=y e s, 0=$ no) & 7056 & 0 & 1 & 0,103 & 0,0046 \\
\hline \multicolumn{6}{|l|}{ Ideology } \\
\hline Practicing Catholic (1=yes, $0=$ no) & 7056 & 0 & 1 & 0,266 & 0,0067 \\
\hline \multicolumn{6}{|l|}{ Knowledge } \\
\hline Informed about S\&T (1=very uninformed, to $5=$ very informed) & 6936 & 1 & 5 & 2,561 & 0,0173 \\
\hline Knowledge of science (0-10 scale) & 7056 & 0 & 10 & 5,700 & 0,0327 \\
\hline Respondent has science degree ( $1=y e s, 0=$ no $)$ & 7056 & 0 & 1 & 0,055 & 0,0036 \\
\hline \multicolumn{6}{|l|}{ Values/beliefs } \\
\hline Trust in scientific/technical professionals & 6613 & 3 & 15 & 12,254 & 0,0360 \\
\hline General outlook on the benefits of S\&T & 7056 & 2 & 10 & 7,137 & 0,0249 \\
\hline Benefits of S\&T outweigh the harms ( $1=y e s, 0=$ no) & 6956 & 0 & 1 & 0,453 & 0,0074 \\
\hline Motivation of scientists ( $1=$ altruistic, $0=$ selfish) & 7056 & 0 & 1 & 0,266 & 0,0067 \\
\hline \multicolumn{6}{|l|}{ Policy attitudes } \\
\hline \multicolumn{6}{|l|}{ Regional context } \\
\hline Percent of regional gov budget for S\&T & $17(7056)$ & 0,35 & 2,99 & 1,26 & -- \\
\hline
\end{tabular}

NOTE: Weighted means and proportions reported above. Taylor linearized standard errors. The regional variables are disaggregated from 17 regions to 7056 individual respondents. 


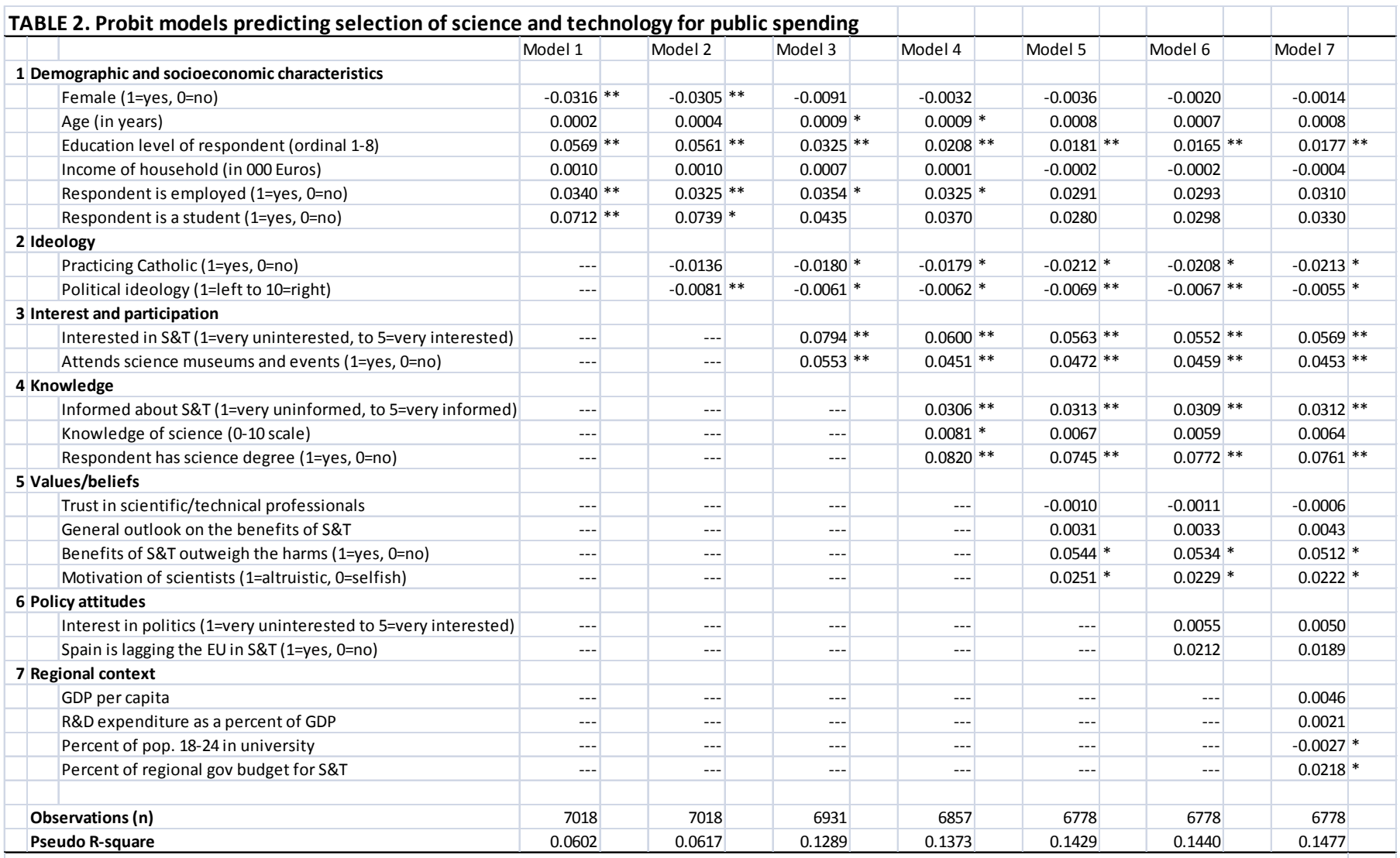

Note: Coefficients shown are marginal changes in probabilities from dprobit in Stata 11 . Significance tests based on clustered (by region) robust standard errors. $* p<.05 * * p<.01$ 
TABLE 3. OLS models predicting expressed support for government spending on science and technology

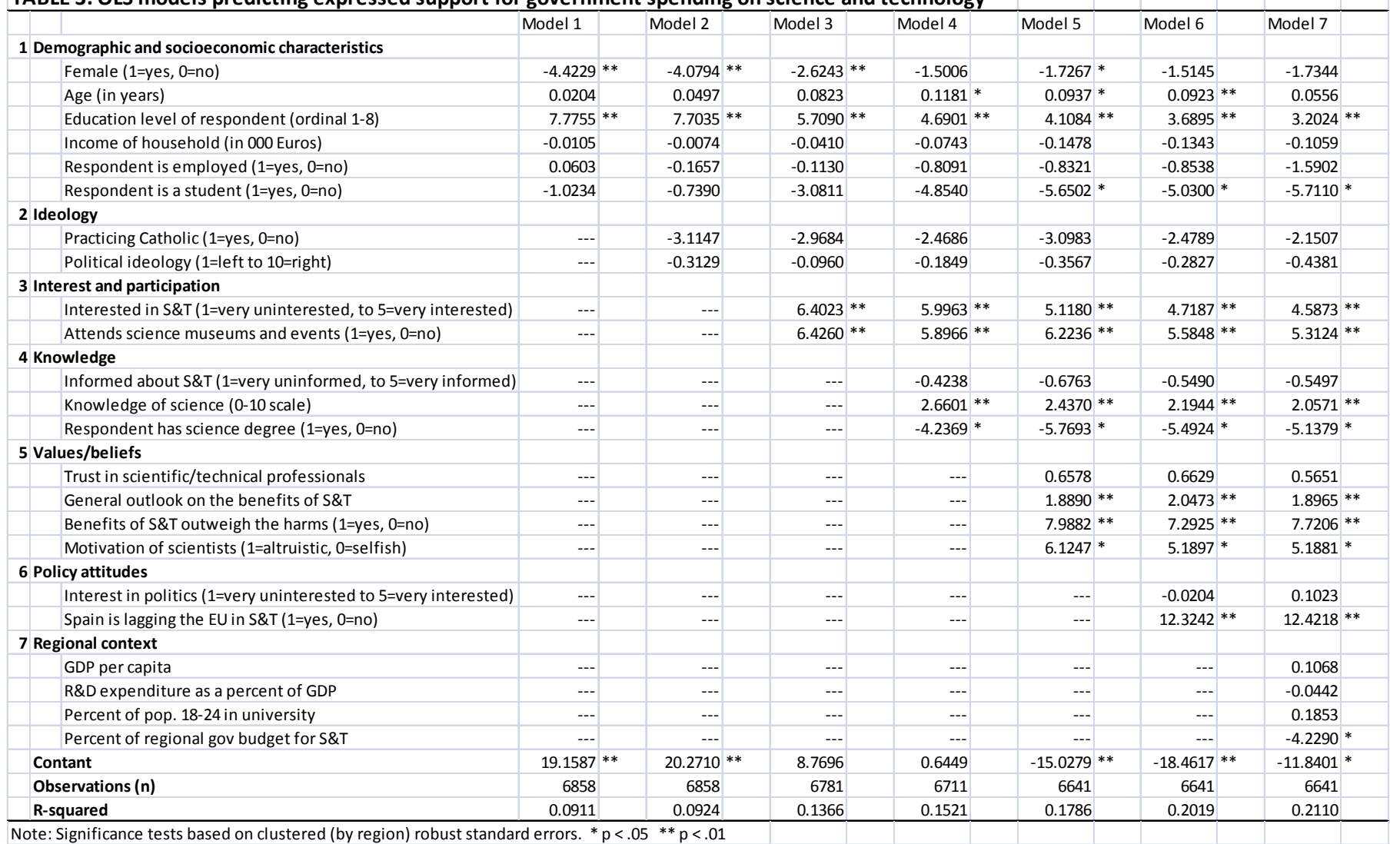

Note: Significance tests based on clustered (by region) robust standard errors. ${ }^{*} p<.05{ }^{* *} p<.01$ 